\title{
INFLUENCE OF TIRE PRESSURE ON NOISE ROAD
}

\begin{abstract}
The article concerns the analysis of the influence of pressure on the noise generated by tires. The largest source of noise and vibrations is the cooperation of the wheels with the surface and the aerodynamic noise. For this purpose, seven winter tires, seven summer tires and one all-season tire were tested in the same region and same conditions. By changing the pressure in them in the range of 1-3 bar, the noise of the tires was measured. On the basis of the conducted tests, it can be concluded that with the decrease of tire pressure, the noise level of the tire decreases. The average noise drop recorded during tests for all types of tested tires is about $1.5 \mathrm{~dB}$ at a pressure drop of approx. 2 bar. The decrease in noise at reduced pressure is also dependent on the size of the tire and the softness of the mixture used for the production of tires. When operating the vehicle, follow the manufacturer's tire pressure recommendations.
\end{abstract}

Keywords: Road noise, Tire, Pressure

Piotr Gorzelanczyk ${ }^{1}$

${ }^{I}$ Stanislaw Staszic University of Applied Sciences in Pila, ul. Podchorazych 10, 64-920 Pita; piotr.gorzelanczyk@puss.pila.pl

Patryk Wlad ${ }^{2}$

${ }^{2}$ Stanislaw Staszic University of Applied Sciences in Pila, ul. Podchorazych 10, 64-920 Pita; p.wlad@wp.pl

Martin Jurkovič $\breve{3}^{3}$

${ }^{3}$ Faculty of Operation and Economics of Transport and Communications, University of Žilina, Univerzitná 1,01026 Žilina, Slovakia; martin.jurkovic@fpedas.uniza.sk

Tomáš Kalina ${ }^{4}$

${ }^{4}$ Faculty of Operation and Economics of Transport and Communications, University of Žilina, Univerzitná 1, 01026 Žilina, Slovakia; tomas.kalina@fpedas.uniza.sk

\section{Introduction}

After 1990, the transport system in Poland was entering a period of transformation, including transport infrastructure, including road infrastructure. It mainly concerned quantitative aspects - length, density of the network. The quality side of the Polish transport infrastructure was much worse at the time (national pressures, practical capacity, internal and external integration of transport networks, surface quality, engineering solutions to improve safety and reduce environmental pollution departed from European standards).

The impact of negative qualitative characteristics of transport infrastructure, in particular road infrastructure, was limited as a result of low traffic levels. In the initial period only punctual infrastructural barriers to the work of road transport appeared (border crossings, bridges, especially on the Vistula, crossings through large agglomerations). Nowadays, we are collecting the harvest of twenty years of lack of major infrastructural investments, and even the lack of adequate replacement and maintenance measures in relation to our infrastructure (urgent repair requires a minimum of $35 \%$ of national roads).

In many places, road infrastructure becomes an obstacle to the efficient development of the region and efficient road transport. For example, an EU driver will drive an average of $9 \mathrm{~km}$ driving $800 \mathrm{~km}$, and in Poland it is only around $500 \mathrm{~km}$. Driving conditions, driving time and accompanying safety leave much to be desired. The necessity to raise the standards of Polish road infrastructure is a requirement set by the European Union. It stipulates that pressure standards should amount to 11.5 tons per axle, which currently only meets $450 \mathrm{~km}$ of Polish roads. At the same time, it must be stated that one 40-ton truck damages the road as well as 0.5 million passenger cars.

The number of vehicles traveling on Polish roads, roads in Wielkopolska and the whole country is growing year by year, as shown in Figure 1. For this reason, the condition of road infrastructure is very important, not only for drivers, but also for inhabitants of towns and villages. The condition of the road surface may cause increased noise. For this reason, the article analyses the influence of tire pressure on the generated noise. A similar problem was considered in the works (Gorzelanczyk, 2012, Gorzelanczyk, 2016, Gorzelanczyk, 2017, Gorzelanczyk and Kaczmarek, 2019, Gorzelanczyk and Michas, 2019, Gorzelanczyk and Sikora, 2019, Gorzelanczyk et al., 2018). 


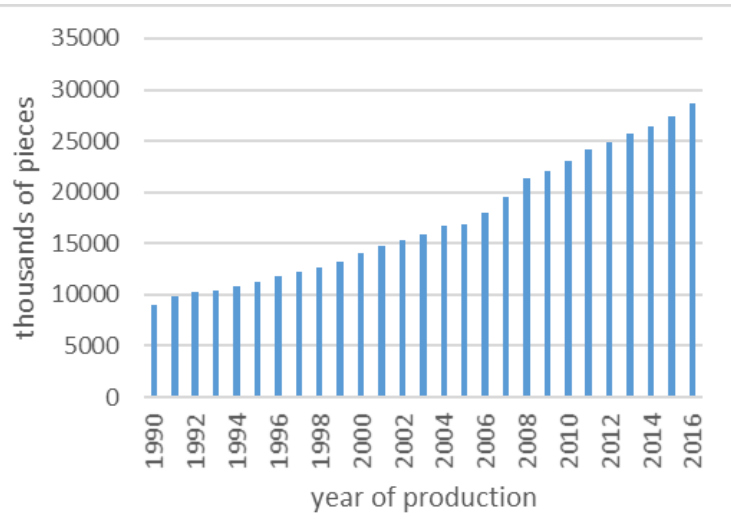

Fig. 1. The number of means of transport in Poland in the years 1990-2016 (Central register of vehicles and drivers 2019)

The problem of the impact of noise on the human body is complex and difficult. It refers to man as an intellectual unit and individuals of the social group, as well as all aspects of his life. For a long time, we have been striving to understand the impact of noise on health, and hence the functions of individual organs and its impact on productivity and quality of work. Equally important is the manifestation of subjective experiences and the individual relationship of the person and the entire society living in conditions of permanent impact of onerous sounds. Population, and all areas of their life are subject to the influence of noise, where the effects of this influence are negative. It is a problem of undoubted importance for both an individual and for the whole of society. The more so because the sources of noise are more and more, they occur in every space of human stay and become a threat to more and more people. Noise remained one of the key factors determining the quality of life of the society in large urban agglomerations. The intensity of noise, its origin, type and variability in time related to the essence of the place in question are determined by the acoustic climate (Gronowicz, 2004, Grzesik, 1975, Sadowski, 2001).

Communication noise is currently one of the most widespread and dominant among noise sources. In particular, road noise is becoming more and more important in view of the dynamic growth in the number of vehicles on Polish roads. At present, efforts are being made to reduce the noise of means of transport. Based on the noise measurement results collected by the Environmental Protection Inspection, it appears that the number of people at risk of noise in Poland is in the range of $13-15$ million, and the average equivalent noise level in urban areas is about $72.4 \mathrm{~dB}$ (Kucharski, 1999). For this reason, measures should be taken to reduce and monitor traffic noise.

Motor vehicles consist of many systems and components. They are a complicated technical system. It contains, among others: engine, various gears, suspension, brake systems and exhaust system. Many elements of road construction are based on bearings, and all these elements are sources of noise (Gronowicz, 2004, Łaszkiewicz, 1992).
Currently, it is believed that the largest source of noise and vibrations is the cooperation of the wheels with the surface and the aerodynamic noise. The location of the main noise sources of the moving means of transport is presented using the acoustic map of the vehicle with the engine running in the wind tunnel (Figure 2)

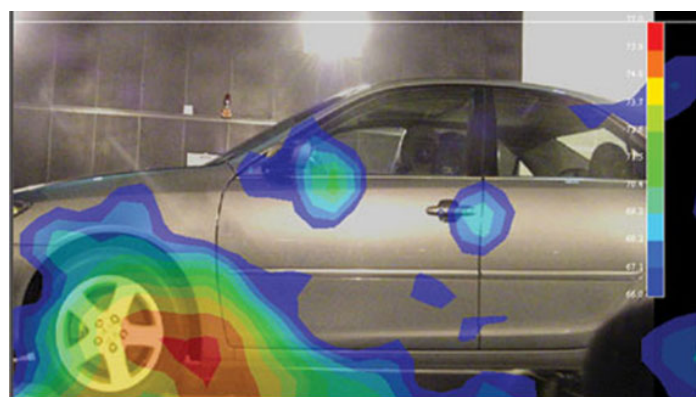

Fig. 2. Acoustic map of the vehicle with the engine running in the wind tunnel (Burdzik, 2012)

Traffic noise at the present time is a dominant and common threat, affecting the acoustic climate of many urban agglomerations. This is connected with the dynamically developing road network in recent years and a large number of means of transport moving on them. This situation causes intensive development of research into the recognition of phenomena that affect the propagation of sounds in the urban agglomeration (Gaja et al., 2003, Li et al., 2002, Morillas et al., 2001, Lipowczan, 1987).

\section{Noise Generated by Tires}

The last of the issues related to the road infrastructure of the Pila region is the noise generated by tires. It depends on the pressure in the tires as well as on the condition of the roads. Currently, the produced tires must meet the increasingly higher requirements of the consumer market. They must not only be very durable, but also have good adhesion and low rolling coefficient. Despite the use of more than 200 ingredients for the production of each tire, we can classify them into groups such as rubber, synthetic rubber, silica, carbon black, textile fibers, chemicals and metals. Despite such an extensive structure, tires are an element that does not undergo major changes (Oponeo, 2018). The construction of a car tire with the specified internal elements is shown in the Figure 3.

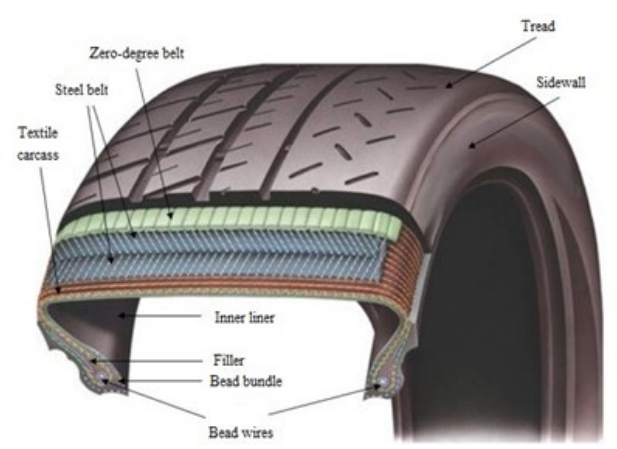

Fig. 3. Car tire (Oponeo, 2018) 
We divide the tires due to their construction, application or specificity of the mixture from which they were made, due to the time of the year during which they best perform their task, whether the tread pattern and its depth. Diagonal and radial tires are the most popular. The diagonal tire is created by arranging several layers of cord arranged alternately in two directions at an angle other than $90^{\circ}$. With this design, higher stiffness is achieved than in radial tires. However, the radial tire was created by radially arranging the warp cord, which increases the flexibility of its side. Applying several layers of belting, we obtain a stiffening of the tire front. Such a construction solution increases the contact area of the tire with the surface. Compared to a diagonal tire, we obtain less angular deflection, less rolling resistance and lower resistance to mechanical damage (Andrzejewski, 2010, Jaworski, 1987.

\section{Research Methodology}

A The noise level generated by the tires was based on the sound level meter of motor vehicles AS-200 from SONOPAN (Figure 4). The meter is designed to measure the sounds produced by motor vehicles. It is also used to assess the volume of audio signals. After the measurements are completed, the meter can be connected to the computer to print a test report (AGK Partner, 2019). Noise measurement was carried out in accordance with applicable regulations, and the measurement set is certified by the Motor Transport Institute.

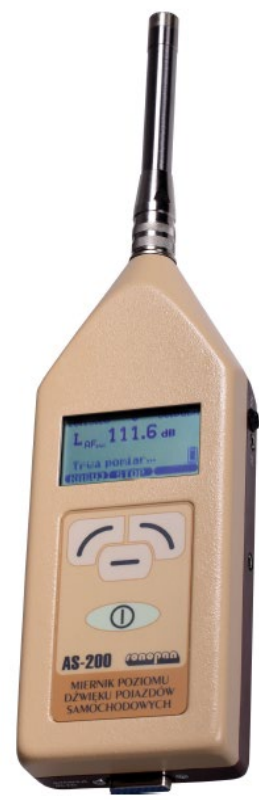

Fig. 4. SONOPAN AS-200 (AGK Partner, 2019)

The place selected for measurements is a section of an asphalt road about $500 \mathrm{~m}$ long located in the Pila region. Measurements were made only in such conditions that external factors would not have a greater impact on the results. The tests were carried out at a temperature of $6^{\circ} \mathrm{C}$ to $20^{\circ} \mathrm{C}$, as well as in sunny weather or a slight cloud cover. The aim was to take measurements with low air humidity, and what is involved, on dry asphalt. The research covered cars with tires with a tread depth higher than $2.5 \mathrm{~mm}$ measured from the TWI marker or higher than $4 \mathrm{~mm}$ measured from the bottom of the groove between the blocks. The device has been selected for measurements due to its high accuracy, easy access and simple operation.

The test was carried out according to the following procedure, and the results are presented in the table and in the chart:

- The driver accelerates the car to a speed of $60 \mathrm{~km} / \mathrm{h}$,

- Turns off the ignition of the speeding car $20 \mathrm{~m}$ before the point of measurement,

- The AS-200 device placed at $1 \mathrm{~m}$ to $1.5 \mathrm{~m}$ from the car's path measures the volume of the passing vehicle,

- The result is saved on the measurement card,

- The driver lowers the pressure in the tires to make the next pass. The initial pressure is 3.0 bar and the final 1.0 bar. Reduction by 0.2 bar.

\section{Research Object}

The tests were carried out on 8 cars. Seven of them were equipped with winter and summer tires, and the seventh with all-season tires. The tires were made by different manufacturers and in different sizes. The data of the analysed tires are presented in Table 1. 
Table 1. Vehicles and tires used to make measurements

\begin{tabular}{|c|c|c|c|}
\hline Name and model & $\begin{array}{c}\text { Year of } \\
\text { production }\end{array}$ & Test summer tire & Test winter tire \\
\hline $\begin{array}{l}\text { Mercedes Benz E280 } \\
\text { CDI }\end{array}$ & 2006 & $\begin{array}{c}\text { Goodyear } \\
\text { EfficientGrip 245/45 } \\
\text { R18 }\end{array}$ & BF Goodrich Winterg 215/55 R16 \\
\hline Chevrolet Lacetti & 2005 & $\begin{array}{c}\text { Debica Presto } 195 / 55 \\
\text { R } 15\end{array}$ & Sava Eskimo S3 185/55 R 15 \\
\hline Ford Mondeo & 2008 & $\begin{array}{c}\text { Nokian zLine XL } \\
225 / 45 \text { R18 }\end{array}$ & GOODYEAR Ultra Grip 215/55 R16 \\
\hline Volkswagen Passat & 2001 & $\begin{array}{c}\text { Hankook PRIME3 } \\
\text { 205/55 R16 }\end{array}$ & Debica Frigo 2 195/65 R15 \\
\hline Opel Insignia & 2011 & $\begin{array}{l}\text { YOKOHAMA } 225 / 35 \\
\text { R19 }\end{array}$ & Vredestein WintracXtreme 255/35R19 \\
\hline Audi A4 & 2006 & \multicolumn{2}{|c|}{$\begin{array}{l}\text { Pirelli CINTURATO ALL SEASON 205/55 R16 } \\
\text { (all-season tire) }\end{array}$} \\
\hline Renault Laguna & 2010 & $\begin{array}{c}\text { Vredestein Ultrac } \\
\text { Sessanta XL 225/40 } \\
\text { R18 }\end{array}$ & Continental Wintercontact TS860 225/45 R18 \\
\hline Kia Pro'ceed & 2008 & $\begin{array}{c}\text { UNIROYAL } \\
\text { RAINSPORT } 3 \\
215 / 55 \mathrm{R} 17\end{array}$ & HANKOOK WINTER CEPT EVO2 215/55R17 \\
\hline
\end{tabular}

\section{Results}

Based on the data from Table 2, it can be concluded that the noise generated by the tires is highly dependent on the pressure in them (Figure 5). The pressure drop reduces the external noise produced by the tires.

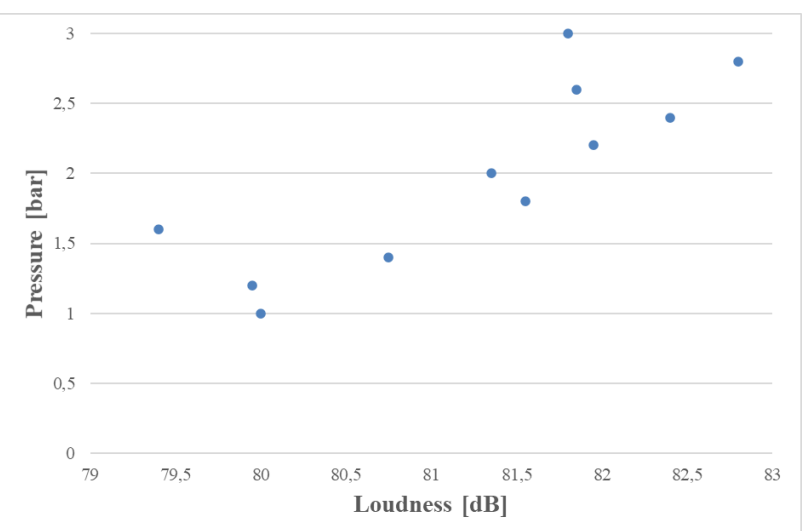

Fig. 5. The average noise value of all tested tires at different pressures

The average noise drop recorded during tests for all types of tested tires is about $1.5 \mathrm{~dB}$ at a pressure drop of approx. 2 bar. The decrease in noise at reduced pressure is also dependent on the size of the tire and the softness of the mixture used for the production of tires. The Goodyear EfficientGrip 245/45 R18 summer tire (81.70 $\mathrm{dB}$ ) was the loudest of the tested tires. installed in the Mercedes Benz E280 CDI, while the winter tire Dębica Frigo 2 195/65 R15 (78.50 dB) installed in the Ford Mondeo turned out to be the quietest. The difference between the volume of the tested tires is over $3 \mathrm{~dB}$.
In most of the analysed tires, summer tires turned out to be louder than winter tires. Only in one case was the summer tire quieter for the Kia Pro'ceed. The tested all-season tire is a noisy tire. Among the summer tires the Uniroyal Rainsport 3215 / 55R17 (80.43dB) was the quietest and the Goodyear EfficientGrip 245/45 R18 $(81.70 \mathrm{~dB})$ was the loudest. The quietest winter tire was the Dębica Frigo 2 195/65 R15 (78.50 dB), which was the quietest tire in the Vredestein WintracXtreme 255 / 35R19 test $(81.13 \mathrm{~dB})$. 
Table 2. Tire volume measurement results

\begin{tabular}{|c|c|c|c|c|c|c|c|c|c|c|c|c|c|c|c|c|}
\hline \multirow[b]{4}{*}{$\begin{array}{c}\text { Pressure } \\
\text { [bar] }\end{array}$} & \multicolumn{2}{|c|}{$\begin{array}{c}\text { Mercedes Benz E280 } \\
\text { CDI } \\
\end{array}$} & \multicolumn{2}{|c|}{ Chevrolet Lacetti } & \multicolumn{2}{|c|}{ Ford Mondeo } & \multicolumn{2}{|c|}{ Volkswagen Passat } & \multicolumn{2}{|c|}{ Opel Insygnia } & Audi A4 & \multicolumn{2}{|c|}{ Renault Laguna } & \multicolumn{2}{|c|}{ Kia Pro'ceed } & \multirow{4}{*}{$\begin{array}{l}\text { Arithmetic } \\
\text { average }\end{array}$} \\
\hline & \multicolumn{2}{|c|}{ Loudness [dB] } & \multicolumn{2}{|c|}{ Loudness [dB] } & \multicolumn{2}{|c|}{ Loudness [dB] } & \multicolumn{2}{|c|}{ Loudness $[\mathrm{dB}]$} & \multicolumn{2}{|c|}{ Loudness [dB] } & Loudness [dB & \multicolumn{2}{|c|}{ Loudness [dB] } & \multicolumn{2}{|c|}{ Loudness $[\mathrm{dB}]$} & \\
\hline & $\begin{array}{c}\text { Summer } \\
\text { tire }\end{array}$ & $\begin{array}{l}\text { Winter } \\
\text { tire }\end{array}$ & $\begin{array}{c}\text { Summer } \\
\text { tire }\end{array}$ & $\begin{array}{c}\text { Winter } \\
\text { tire }\end{array}$ & $\begin{array}{c}\text { Summer } \\
\text { tire }\end{array}$ & $\begin{array}{c}\text { Winter } \\
\text { tire }\end{array}$ & \begin{tabular}{c|} 
Summer \\
tire
\end{tabular} & \begin{tabular}{|c|} 
Winter \\
tire
\end{tabular} & $\begin{array}{c}\text { Summer } \\
\text { tire }\end{array}$ & $\begin{array}{c}\text { Winter } \\
\text { tire }\end{array}$ & $\begin{array}{c}\text { All-season } \\
\text { tire }\end{array}$ & $\begin{array}{c}\text { Summer } \\
\text { tire }\end{array}$ & $\begin{array}{c}\text { Winter } \\
\text { tire }\end{array}$ & \begin{tabular}{|c|} 
Summer \\
tire
\end{tabular} & $\begin{array}{c}\text { Winter } \\
\text { tire }\end{array}$ & \\
\hline & $\begin{array}{c}\text { Goodyear } \\
\text { EfficientGri } \\
\text { p 245/45 } \\
\text { R18 }\end{array}$ & \begin{tabular}{|c} 
BF \\
Goodrich \\
Winterg \\
$215 / 55$ \\
R16
\end{tabular} & \begin{tabular}{|c} 
Debica \\
Presto \\
$195 / 55 \mathrm{R}$ \\
15
\end{tabular} & \begin{tabular}{|c|} 
Sava \\
Eskimo \\
S3 \\
$185 / 55$ \\
R 15
\end{tabular} & $\begin{array}{c}\text { Nokian } \\
\text { zLine XL } \\
225 / 45 \\
\text { R18 }\end{array}$ & $\begin{array}{c}\text { GOOD } \\
\text { YEAR } \\
\text { Ultra } \\
\text { Grip } \\
215 / 55 \\
\text { R16 }\end{array}$ & $\begin{array}{c}\text { Hankook } \\
\text { VENTUS } \\
\text { PRIME3 } \\
\text { K125 } \\
205 / 55 \\
\text { R16 }\end{array}$ & \begin{tabular}{|c|} 
Debica \\
Frigo 2 \\
$195 / 65$ \\
R15
\end{tabular} & \begin{tabular}{|c|} 
YOKOH \\
AMA \\
$225 / 35$ \\
R19
\end{tabular} & \begin{tabular}{|c|} 
Vredestei \\
n Wintrac \\
Xtreme S \\
255/35R19
\end{tabular} & $\begin{array}{c}\text { Pirelli } \\
\text { CINTURAT } \\
\text { O ALL } \\
\text { SEASON } \\
\text { 205/55 R16 }\end{array}$ & $\begin{array}{c}\text { Vredestei } \\
\text { n Ultrac } \\
\text { Sessanta } \\
\text { XL } \\
225 / 40 \\
\text { R18 }\end{array}$ & \begin{tabular}{|c|} 
Contin \\
ental \\
Winter \\
contact \\
TS860 \\
$225 / 45$ \\
R18
\end{tabular} & $\begin{array}{c}\text { UNIRO } \\
\text { YAL } \\
\text { RAINS } \\
\text { PORT 3 } \\
215 / 55 R \\
17\end{array}$ & $\begin{array}{c}\text { HANK } \\
\text { OOK } \\
\text { WINT } \\
\text { ER } \\
\text { CEPT } \\
\text { EVO2 } \\
215 / 55 \\
\text { R17 }\end{array}$ & \\
\hline 3 & 82,3 & 81,3 & 81,7 & 81 & 82,1 & 80,8 & 81,4 & 78,7 & 82,5 & 81,7 & 81,7 & 82 & 81,9 & 80,7 & 81,7 & 81,35 \\
\hline 2,8 & 83,2 & 82,4 & 80,6 & 79,8 & 81 & 80,4 & 79,8 & 79,5 & 82,2 & 82,1 & 81,9 & 81,3 & 82 & 81,1 & 81,6 & 81,16 \\
\hline 2,6 & 82,9 & 80,8 & 81,9 & 78 & 82,4 & 78,8 & 81,8 & 78,2 & 82,7 & 82,3 & 81,7 & 81,5 & 80,6 & 81 & 81,2 & 81,01 \\
\hline 2,4 & 82,2 & 82,6 & 80,4 & 79,8 & 80,8 & 79,4 & 80,9 & 79,1 & 81,8 & 81,2 & 82 & 81,4 & 80,9 & 81,3 & 80,8 & 80,82 \\
\hline 2,2 & 82,6 & 81,3 & 81,4 & 77,9 & 81,1 & 78,9 & 80,9 & 78,1 & 80,9 & 81,3 & 81,3 & 81,3 & 81 & 80,8 & 81,2 & 80,70 \\
\hline 2 & 80,1 & 82,6 & 80,6 & 79 & 81,6 & 79,2 & 81,4 & 79,2 & 81 & 80,1 & 81,6 & 82 & 81,2 & 80,5 & 81 & 80,72 \\
\hline 1,8 & 82,7 & 80,4 & 81,6 & 77,6 & 81,6 & 78,6 & 81,8 & 78,2 & 80,8 & 81,3 & 81,8 & 81,2 & 81 & 80,7 & 81,1 & 80,42 \\
\hline 1,6 & 79,4 & 79,4 & 79,9 & 78,6 & 80,8 & 78,7 & 80,8 & 78,3 & 81,1 & 80,8 & 81 & 81,8 & 80,8 & 80,1 & 80,7 & 80,19 \\
\hline 1,4 & 82,3 & 79,2 & 81,1 & 78,4 & 81,2 & 78,2 & 80,2 & 77,9 & 80,7 & 80,9 & 81,1 & 80,9 & 80,9 & 80,1 & 80,5 & 80,11 \\
\hline 1,2 & 79,4 & 80,5 & 80,7 & 78,3 & 81,2 & 78,4 & 81,2 & 78,3 & 80,8 & 80,3 & 79,9 & 80,8 & 80,7 & 79,3 & 80 & 79,96 \\
\hline 1 & 81,6 & 78,4 & 80,3 & 78,6 & 81 & 78,1 & 80,1 & 78 & 80,2 & 80,4 & 80,7 & 81,2 & 81 & 79,1 & 80,3 & 80,29 \\
\hline erage & 81,70 & 80,81 & 80,93 & 78,82 & 81,35 & 79,05 & 80,94 & 78,50 & 81,34 & 81,13 & 81,34 & 81,40 & 81,09 & 80,43 & 80,92 & 80,65 \\
\hline
\end{tabular}

\section{Conclusions}

Based on the data presented in the article, it can be concluded that the noise level of the tested tires decreases with the decrease in tire pressure. The summer tires turned out to be the loudest, and the winter ones were the quietest. The difference was very big as it exceeded $3 \mathrm{~dB}$. The all-season tire was in the upper range of the tested tires. However, despite the results presented above, they should not be considered, but only the vehicle should be operated at the pressure recommended by the car manufacturer.

\section{References}

AGK Partner. 2019 Noise meter for motor vehicles. Cited 1.5.2019 http://agkpartner.pl/data/documents/miernikas200.pdf

Andrzejewski R. 2010 Dynamics of the pneumatic wheel. Scientific and Technical Publisher. Warsaw.

Burdzik R. 2012. Tire noise tests. Scientific issues of the Silesian University of Technology. Series Transport $77 / 1878$.

Central register of vehicles and drivers. 2019 The number of means of transport in Poland. Cited 1.5.2019 Online: http://www.cepik.gov.pl/statystyki

Gaja F. et al. 2003 Sampling techniques for the estimation of the annual equivalent noise level Urban traffic conditions. Applied Acoustics.

Gorzelańczyk P. 2017 Characteristics of tires used by public transport buses in the city of Pila, Coaches" Technology, Operation, Transport Systems.

Gorzelańczyk P. 2016 Condition of varnish coatings of vehicles used in various climatic zones, "Coaches" Technology, Operation, Transport Systems, Vol. 6, p. 871-875.

Gorzelańczyk P. 2012 Expert systems in the diagnostics of means of transport, Logistics 3/2012.

Gorzelańczyk P., Kaczmarek Ł. 2019 Impact of modern information systems on the operation of passenger vehicles. Coaches. Technology, Operation, Transport Systems, 1/2019.

Gorzelańczyk P., Michaś D. 2019 The impact of Eco-driving on the operation of vehicles, Coaches. Technology, Operation, Transport Systems, 1/2019.

Gorzelańczyk P., Sikora K. 2019 Research and technicaloperational analysis of mechanical and electrical parking brakes" Coaches. Technology, Operation, Transport Systems, 1/2019.

Gorzelańczyk P., Wachowiak P., Kalina T. 2018. Analysis of the effectiveness of shock absorbers in the light of applicable legal regulations in Poland and Slovakia, Coaches. Technology, Operation, Transport Systems, 6/2018.

Gronowicz J. 2004 Environmental protection in land transport, Publisher of the Institute of Sustainable Technologies, Radom.

Grzesik J. 1975 Acoustic stimuli. PWN, Warsaw.

Jaworski J. 1987 Motor vehicle tires. Publishing House for Communication and Communications, Warsaw.

Kucharski R. J. 1999 Noise in communication noise in Poland Ekopartner number 05.

Li B., Tao S., Dawson R.W. 2002 Evaluation and analysis of traffic noise from the main Urban Road In Beijing. Applied Acoustics.

Lipowczan A. 1987 Basics of noise measurement Publisher GiG, Katowice.

Łaszkiewicz T. 1992 What and how the cars are making noise Automotive Scientific and Technical Quarterly (III).

Morillas J.M., Escobar G.V., Sierra J.A.M. Gómez R.V. 2001 An environmental noise study in the city of Caceres. Spain. Applied Acoustics.

Oponeo. 2018 Tyre construction-functions of individual elements. Cited 1.12.2018 Online:

https://www.oponeo.co.uk/tyre-article/tyre-constructionfunctions-of-individual-elements

Sadowski J. 2001 The acoustic climate of the environment. Aura number 